\title{
Criminological principles of crime prevention in the field of physical culture and sports of Ukraine
}

Principios criminológicos de la prevención de la delincuencia en el ámbito de la cultura física y el deporte de Ucrania

\section{Princípios criminológicos de prevenção do crime no campo da cultura física e dos esportes da Ucrânia}

\author{
Olexandr M. Dzhuzha ${ }^{1}$ \\ Vitaly V. Vasylevych ${ }^{2}$ \\ Bohdan M. Telefanko ${ }^{3}$ \\ Nataliia E. Filipenko ${ }^{4}$
}

Received: March 9 ${ }^{\text {th }}, 2021$

Accepted: April $6^{\text {th }}, 2021$

Published: July $6^{\text {th }}, 2021$

How to cite this article:

Olexandr M. Dzhuzha, Vitaly V. Vasylevych, Bohdan M. Telefanko \& Nataliia E. Filipenko. Criminological principles of crime prevention in the field of physical culture and sports of Ukraine.

DIXI, vol. 23, n. 2, julio-diciembre 2021, 1-14.

DOI: https://doi.org/10.16925/2357-5891.2021.02.10

Research article. https://doi.org/10.16925/2357-5891.2021.02.10

1 Doctor of Law, Professor, Honored Lawyer of Ukraine, Chief Researcher Fellow at the Department of Organization of Scientific Activity and Intellectual Property Rights of the National Academy of Internal Affairs, Kyiv, Ukraine.

E-mail: ddt0099@gmail.com

ORCID: https://orcid.org/0000-0003-1347-4937

$2 \mathrm{PhD}$ in Law, Professor, Scientific Secretary of the Secretariat of the Academic Council, National Academy of Internal Affairs, Kyiv, Ukraine.

E-mail: vavian3@ukr.net

ORCID: https://orcid.org/0000-0001-9351-4219

3 Candidate of Legal Sciences, Associate Professor at the Department of Law for Lviv National University of Veterinary Medicine and Biotechnologies C. Z. Grzycki, Lviv, Ukraine.

E-mail: telefbm@i.ua

ORCID: https://orcid.org/0000-0002-4682-3622

$4 \quad \mathrm{PhD}$ in Law, Associate Professor at the Department of Law of National Aerospace University Kharkiv Aviation Institute, Kharkiv, Ukraine.

E-mail: filipenko_natalia@ukr.net

ORCID: https://orcid.org/0000-0001-9469-3650 


\section{Abstract}

The purpose of this paper is to examine to what extent Ukraine has established the criminological foundation to ensure its prevention in the field of physical culture and sport. The commission of crimes has always been increasing in societies, albeit with the existence of credible principles and sanctions. We all know that in the field of physical culture and sport there are experiences of crimes of all kinds, which has affected the very existence of this discipline. There is no way to have effective recognition of these fields if appropriate measures and not taken to curb the crime level in the areas. Crime in the field of physical culture and sports covers almost every type of crime in the Special Part of Criminology. The current lack of objective data in the state statistics on the topics of our interest, and the urgent need to study crimes in the sphere of physical culture and sports, require the development of appropriate conceptual approaches to collect and summarize our own empirical information, taking into account the tasks of this research and the prospects of application of the obtained results in the practical activities of police units. The authors of the article have tried to develop the criminological characteristics and crime prevention in the field of physical culture and sports. The authors have emphasized the high latency of this type of crime, as well as the methodology of research of this phenomenon; they have revealed the brief characteristics of the criminal's personality in the field of physical culture and sports. Preventive measures against these crimes have been substantiated. Proposals to improve the legal regulation of criminal and legal prevention of criminal encroachments within sports have been provided. The priority task of the modern state is the formation of a healthy nation and the proper guaranteeing and regulation of various spheres of public life, which should contribute to the improvement of health and physical and spiritual development of the population. Such areas as physical culture and sports are not the least important. Today, some socially dangerous phenomena have taken root in Ukraine in this area, in particular, corruption, injuries, mortality, etc.

Keywords: Criminological characteristics, empirical basis, latency, legislative prevention, sphere of physical culture and sports, sports crime, victimological prevention.

\section{Resumen}

El objetivo de este trabajo es examinar en qué medida Ucrania ha establecido las bases criminológicas para garantizar su prevención en el ámbito de la cultura física y el deporte. La comisión de delitos siempre ha ido en aumento en las sociedades, aunque con la existencia de principios y sanciones creíbles. Todos sabemos que en el ámbito de la cultura física y el deporte hay experiencias de delitos de todo tipo, lo que ha afectado a la propia existencia de esta disciplina. No hay manera de tener un reconocimiento efectivo de estos campos si no se toman las medidas adecuadas para frenar el nivel de delincuencia en las zonas. La delincuencia en el ámbito de la cultura física y el deporte abarca casi todos los tipos de delitos de la Parte Especial de la Criminología. La actual falta de datos objetivos en las estadísticas estatales sobre los temas de nuestro interés, y la urgente necesidad de estudiar los delitos en el ámbito de la cultura física y el deporte, requieren el desarrollo de enfoques conceptuales adecuados para recoger y resumir nuestra propia información empírica, teniendo en cuenta las tareas de esta investigación y las perspectivas de aplicación de los resultados obtenidos en las actividades prácticas de las unidades policiales. Los autores del artículo han tratado de desarrollar las características criminológicas y la prevención del delito en el ámbito de la cultura física y el deporte. Los autores han destacado la alta latencia de este tipo de delitos, así como la metodología de investigación de este fenómeno; han revelado las breves características de la personalidad del delincuente en el ámbito de la cultura física y el deporte. Se han fundamentado las medidas preventivas contra estos delitos. Se han aportado propuestas para mejorar la regulación legal de la prevención penal y jurídica de las invasiones delictivas en el ámbito deportivo. La tarea prioritaria del Estado moderno es la formación de una nación sana y la adecuada garantía y regulación de las diversas esferas de la vida pública, que deben contribuir a la mejora de la salud y el desarrollo físico y 
espiritual de la población. La cultura física y el deporte no son los menos importantes. Hoy en día, en Ucrania se han arraigado algunos fenómenos socialmente peligrosos en este ámbito, en particular, la corrupción, las lesiones, la mortalidad, etc.

Palabras clave: características criminológicas, base empírica, latencia, prevención legislativa, ámbito de la cultura física y el deporte, delincuencia deportiva, prevención victimológica.

\section{Resumo}

O objetivo deste documento é examinar até que ponto a Ucrânia estabeleceu a base criminológica para garantir sua prevenção no campo da cultura física e do esporte. A prática de crimes sempre foi crescente nas sociedades, embora com a existência de princípios e sanções credíveis. Todos sabemos que no campo da cultura física e do esporte existem experiências de crimes de todos os tipos, o que tem afetado a própria existência desta disciplina. Não há como ter um reconhecimento efetivo desses campos se medidas apropriadas não forem tomadas para conter o nível de criminalidade nas áreas. 0 crime no campo da cultura física e do esporte cobre quase todos os tipos de crime na Parte Especial da Criminologia. A atual falta de dados objetivos nas estatísticas estatais sobre os temas de nosso interesse e a necessidade urgente de estudar os crimes na esfera da cultura física e do esporte exigem o desenvolvimento de abordagens conceituais apropriadas para coletar e resumir nossas próprias informações empíricas, levando em conta as tarefas desta pesquisa e as perspectivas de aplicação dos resultados obtidos nas atividades práticas das unidades policiais. Os autores do artigo tentaram desenvolver as características criminológicas e a prevenção da criminalidade no campo da cultura física e do esporte. Os autores enfatizaram a alta latência deste tipo de crime, assim como a metodologia de pesquisa deste fenômeno; revelaram as breves características da personalidade do criminoso no campo da cultura física e do esporte. As medidas preventivas contra estes crimes foram substanciadas. Foram apresentadas propostas para melhorar a regulamentação legal de crimes e a prevenção legal de invasões criminosas dentro do esporte. A tarefa prioritária do Estado moderno é a formação de uma nação saudável e a adequada garantia e regulamentação de várias esferas da vida pública, o que deve contribuir para a melhoria da saúde e do desenvolvimento físico e espiritual da população. Áreas como a cultura física e o esporte não são as menos importantes. Hoje, alguns fenômenos socialmente perigosos se enraizaram na Ucrânia nesta área, em particular, corrupção, lesões, mortalidade, etc.

Palavras-chave: Características criminológicas, base empírica, latência, prevenção legislativa, esfera da cultura física e do esporte, crime esportivo, prevenção vitimológica.

\section{INTRODUCTION}

Sport is currently becoming more organized and regulated. New types of competitions have appeared; rules, limits of admissibility of behavior in sports and responsibility for their violation have been specified; sport has acquired traditions and supporters. Sport has become more professional and that has significantly increased its popularity, which in turn has attracted significant material resources and, consequently, organized forms of promoting leadership.

However, many important aspects of sports are still not covered by the current regulatory acts. It entails an imbalance in the system of norms regulating physical 
culture and sports, and the lack of interaction between law-enforcement employees, increased likelihood of various offenses and their subsequent concealment. Accordingly, public relations in the field of sports directly or indirectly endow a person with the ability and possibility to commit certain offenses. Probability to be involved in criminal activities has been significantly increased for all sports actors.

The most complete study of these circumstances is possible due to criminological research on the corruption component of the financing of physical culture and sports, law enforcement and physical protection of criminal activity carried out by organized criminal groups ${ }^{1}$ formed from former athletes, as well as organized criminal groups that exist under the name of "fan movement".

\section{MATERIAL AND METHODS}

The beginning of the 21st century was marked by a surge in the activity of youth movements. Socio-economic and political transformations in the country, and the processes of integration into the globalized world community have led to the breakdown of former moral values, norms and traditions. Permanent social transformations with insufficient attention of the authorized state authorities to the organization of leisure of children and youth, their employment and recreation, have led to the strengthening of radical movements, the existence of which began to be manifested in the illegal activities of informal associations, including sports ones.

It should be noted that fan crime has obvious and latent manifestations. These include acts of hooliganism and vandalism committed before, during and after competitions in public places in front of a large number of people; and physical influence on opponents in order to ensure the victory of own athlete or team in the competition. And latent criminal manifestations in the field of physical culture and sports include the creation of criminal communities with a clear hierarchy, the internal unity of their members, which are used by the representatives of organized crime to achieve not sports, but financial or political goals. ${ }^{2}$

The current "sports" crime covers almost all types of crime of the Special Part of Criminology. However, the lack of current objective data on government statistics regarding the issues of our interest, and the urgent need to study crimes in the field of physical culture and sports, require the development of appropriate conceptual approaches to collect and summarize own empirical information, taking into account

1 A. V. Shesler. GRoup CRIME: CRIMINOLOGICAL AND CRIMINAL ASPECTS. Saratov State Law Academy. (2006). Pg. 57.

2 S. V. Alekseev. InTERnAtIONAL SPORTS LAW. Yunita-Dana: Legislation and Law. (2008). Pg. 435. 
the objectives of this study and the perspectives for the implementation of the results in the practical activities of police units. Given these circumstances, we were forced to use an in-depth methodology for crime study in the field of physical culture and sports, based on empirical data collected in 2016-2018, obtained as a result of a survey of athletes, employees of training institutions, as well as among visitors to sporting events in Kyiv, Kharkiv and Odessa.

In order to write this article, the authors used general and special methods of scientific knowledge. The methodology includes the following methods:

a) The historical method made it possible to analyze the ways to solve specific problems of crime in the field of physical culture and sports, and formulated conclusions about the feasibility of their use in modern conditions.

b) The comparative legal method provided an opportunity to identify general, special and individual norms in the sports legislation of different countries, and to show similarities and differences in the assessment of legality (illegality) of actions committed by athletes and other representatives of physical culture and sports. The advanced international experience ${ }^{3}$ in crime prevention in the field of physical culture and sports was studied within the framework of this method, and the possibility of its implementation in the activities of domestic structures was considered.

c) The conducted observation over criminal activity of the representatives of physical culture and sports area (mainly athletes who use doping; officials who committed corruption-related crimes; fans who committed hooliganism and organized riots) met all the existing requirements: It was long-lasting, systematic, versatile, objective and mass.

d) The system analysis provided an opportunity to consider the powers of each unit of the National Police in the framework of activities to prevent crimes in the field of physical culture and sports, to identify the problems in their work to optimize their duties.

e) The usage of the modeling method assisted to build and study the most typical criminological models of crimes committed in the field of physical culture and sports:

- In the framework of the crime of athletes related to their direct sports activities - crimes under the Articles 115, 121, 125, 126, 127 of the Criminal Code of Ukraine, in terms of performing official activities;

3 L. A. Rikina. International Cooperation of Ukraine in Combating Crime. SCIENTIFIC BULLETIN OF DNIPROPETROVSK 4. 2004. Pg. 64. 
- Within the framework of crime of athletes not related to their direct sports activities - crimes under the Articles 115, 121, 122, 125, 126, 146, 187, 189 of the Criminal Code of Ukraine;

- In the framework of the crime of other persons related to the sports activities of athletes - crimes under the Articles 115, 121, 122, 125-127 of the Criminal Code of Ukraine in terms of carrying out official activities;

- In the framework of crimes against public order and morality committed by members of youth radical groups in connection with the conduction of football matches (Articles 263, 293-296 of the Criminal Code of Ukraine).

f) Methods of grouping assisted to carry out criminological classifications of types of crime in the field of physical culture and sports (crime of athletes related to their direct sports activities, crime of athletes not related to their direct sports activities, crime of other persons related to sports activities of athletes); their causes and conditions (organizational, cultural, economic); criminals who commit crimes in the field of physical culture and sports, which allowed to derive the average characteristics of persons who commit crimes in the field of sports.

g) The survey in the form of questioning provided an opportunity to find out the opinions of athletes, supporting staff (coaches, heads of training institutions, etc.) and spectators about the circumstances of our interest, to compare the obtained information with other collected information.

h) The method of empirical evaluation was used to obtain reasoned opinions of specialists (athletes, coaches, heads of training institutions for athletes, law enforcement officers), based on their professional, scientific and practical experience. For example, the ratio of lucrative and violent criminals among athletes ${ }^{4}$ on forecasts and ways to reform domestic sports, etc.

i) Content analysis that is a method of collecting documented quantitative data on the studied phenomena. The documents were understood as both official texts (archival criminal cases, criminal proceedings), and magazine articles, books, videos, televised remarks.

Messages published on the official media sites on the Internet were selected as the objects of the study. The content analysis procedure made it possible to determine

4 V. V. Beletskiy. VIOLENT CRIME AND SPORTS. SOCIO-LEGAL PROBLEMS OF COMBATING VIOLENCE: AN INTERUNIVERSITY COLLECTION OF SCIENTIFIC PAPERS. OYUN. (1996). Pg. 209. 
the categories - the main corpus delicti of crimes. This made it possible to determine the range of known crimes in the field of physical culture and sports and measures of responsibility applied to the perpetrators.

\section{RESULT AND DISCUSSION}

Based on criminological and victimological findings, some people are more likely to be victimized than others due to their specific biological, psychological, and social characteristics, and are more potentially vulnerable victims. The dominant culture of society plays an important role in criminalizing or not criminalizing the relations between individuals. It should be noted here that culturalization is much more constructive than creating legal barriers as well as punishing because it costs the government less. Also, prevention is always better than treatment. ${ }^{5}$ Summarizing the used research methodology, we can note several regularities:

- Increased latency of corruption among crimes of other persons related to sports activities of athletes;

- Criminalization of commercial kinds of sports;

- The choice of violence by criminals, other persons related to sports activity of athletes, as the main way of achieving the purpose and realization of motives;

- Increase in cases of embezzlement of funds allocated for the construction of sports facilities;

- The growing number of illegal agreements related to the sale of entrance tickets to prestigious sports competitions;

- Change in the internal structure of sports fans' associations, the emergence of an extensive network of cohesive groups with a clear hierarchy, the internal unity of their members, connected with a common idea, which are used by the representatives of organized crime to implement their criminal plans.

The set of circumstances that determine the existence of crime in the field of physical culture and sports includes a rather wide range of different causes and conditions. All of them can lead to the commission of crimes, but only when interacting

5 Rashin Ziya \& Ahmad Ahmadi. Criminological Study of Domestic Violence in Iran. JURNAL CITA HUKUM (INDONESIAN LAW JOURNAL) 3. 2020. Pg. 525-542. https://doi. org/10.15408/jch.v8i3.18420 
with the personal qualities of a potential offender, ${ }^{6}$ when he/she is already internally ready to break the law. Therefore, while developing programs for the prevention of crimes in the field of physical culture and sports, it is necessary to take into account the traits of probable criminals and the factors that motivate them. We can distinguish the following personal characteristics of these criminals:

1. Socio-demographic criterion:

a) Sports hooliganism is a predominantly male type of crime. The share of women does not exceed 6-7\%;

b) Representatives of the youth group dominate in terms of age characteristics (64.6\%); followed by juvenile offenders (30.1\%); then middle-aged criminals (4.2\%) and finally age-related offenders (1.1\%).

c) According to the level of education, the most numerous group of criminals are those who have secondary and incomplete secondary education (64.3\%). As a rule, many of them did not work or study anywhere $(41.8 \%)$.

The vast majority of sports hooligans does not have families (80.8\%) and live in the area of the crime scene (83.1\%). They have the skills, inclinations and persistent stereotypes of anti-social behavior. Only a few of them commit crimes due to carelessness.

M. M. Rudyk in his study singled out a special category in the structure of football supporters - football fans (according to expert estimates, there are more than 54 thousand football fans in Ukraine, where no more than 30 thousand are officially registered; 1.8 thousand are on preventive registration in police agencies). The main criteria for supporters belonging to the fans are: Active attendance of home matches of the team; several trips to other cities annually; knowledge and acceptance of the subculture. According to the survey, the subjects of group violations of public order are mainly football fans (66.6\%), in particular members of informal youth groups (23.3\%). Crimes are committed mostly by males (92.4\%), aged 18 to 25 (78.4\%), who have a permanent residence (94\%). Almost a third (30.6\%) from those criminally prosecuted members of youth football groups were persons who did not work or study. The majority of minor participants (over

6 Yu. M. Antonian. The Criminal Person and the Criminal's Personality. CRIMINologicaL POINT OF VIEW 3. 2008. Pg. 145-146. 
$60 \%)$ had unfavorable relationships in families, and parents demonstrated indifference to the behavior and upbringing of children.?

2. Criminal and legal criterion: Sports hooliganism and vandalism are mostly group crimes. Moreover, the criminal activity of most hooligans and vandals is not limited in committing one crime. It continues, having more and more brutal, violent forms.

3. Moral and psychological criterion: The hooligan type of criminals in the field of sports, as a rule, does not feel remorse after committing a crime, because he disguises his actions as a demonstration of love for his sports team. The studied personality types of criminals who commit crimes in the field of sports allow us to conclude that they are dominated by representatives of the introverted, situational and selfish-violent type. This should be taken into account while developing comprehensive (target-oriented) preventive programs.

The core of modernization of the current system of physical culture and sports, and its development in Ukraine, should be a reasonable improvement of the system of norms, i.e. the legal framework regulating this area of public relations. Sports legislation needs to be codified, which can make it possible to respond more clearly to changes in life, training conditions for athletes and their participation in competitions.

The general social measures to prevent crimes in the field of physical culture and sports include the following:

1. Stimulating the efficiency of the economy, raising the target activity and initiative of the people, improving the welfare of citizens;

2. Organization of patriotic, cultural and legal education in all institutions, including sports ones.

Among the special criminological measures aimed at preventing the crimes of athletes, we should pay attention to the following areas:

1. Creation of the state target-oriented program of supporting physical culture and sports, the strategic and tactical plan. And we need to start the work with the division of physical culture and sports at the legislative level. Besides, a number of social guarantees should be provided for athletes who

7 M. M. Rudyk. PREVENTION OF CRIMES COMMITTED BY YOUTH FOOTBALL GROUPS IN UKRAINE. Kharkiv National University of Internal Affairs. (2016). Pg. 10. 
have won prizes during international competitions, such as the Olympic Games and the World and European Championships;

2. Training, retraining, employment of athletes who have left the top-class sports. Our content analysis of press reports on crimes committed by athletes showed that on average $30.2 \%$ of them violated the law while being able-bodied, but at the time of its commission did not work or study anywhere;

3. Involvement of charitable foundations to work with athletes, which could provide material assistance to athletes who have lost their jobs, employment and retraining, their adaptation to new living conditions;

4. Prevention of drug addiction, alcoholism and other social disorders in the behavior of former athletes. Athletes who have achieved high results need a program of psychological rehabilitation and assistance in adapting to new "after sports" living conditions.

The implementation of these measures could help athletes to some extent in order to refrain from committing crimes in general and from the most negative decision - to work for criminal communities (criminal organizations). At the same time, we should only state the inattentive attitude of the country and society to current and former athletes, which is not the best reflected in the crime situation in general. In the framework of victimological crime prevention 8 in the field of physical culture and sports, it is necessary to focus on the following activities:

1. Study of possible sources of victim influence on the athlete, including from his immediate environment;

2. Control of behavior and lifestyle of the athlete and potentially dangerous persons (competitors, rivals, promoters, etc.);

3. Training of a potential victim to the methods of self-defense in order to increase personal security, ensuring the prevention and cessation of specific crimes using protective capabilities;

4. Improving the quality of protection of sports facilities during sports events with the introduction of a unified standard of safety of athletes from possible encroachments into practice. This document must contain a real calculation of the forces and means necessary and sufficient to ensure the safety of athletes, without which the competition is considered impossible; 
5. Increasing the responsibility of sports organizations, clubs and their representatives who accompany athletes to competitions, for miscalculations in ensuring the safety of the persons under care.

However, a more complete solution to the existing problems in the field of sports should be facilitated by changing the norms that provide liability for crimes and offenses in the field of sports. To do this, we should make the following amendments to the Criminal Code of Ukraine:

- First of all, amendments that establish criminal liability for the use of substances prohibited in sports by an athlete-participant of international sports competitions - means and substances, for the illegal circulation of which criminal liability is already provided;

- Second, amendments that establish criminal liability for the declension to abuse narcotic drugs and psychotropic substances or their analogues in relation to the athlete;

- Third, amendments that establish criminal liability for unlawful influence on the outcome of an official or professional sporting event or a spectacular commercial competition;

- Fourth, amendments that establish criminal liability for illegal behavior of visitors to sports events at sports facilities.

However, all these amendments will be effective only if there are qualitative activities of law enforcement agencies, including the National Police, which are responsible for detecting and investigating most crimes and offenses in the field of sports. The situation can be changed as soon as possible through the development and adoption of departmental and interdepartmental regulatory acts that can consolidate the efforts of the relevant structures in a priority area for our country, reducing the criminogenic situation of the sports sphere and increasing the safety of sports activities.

In particular, the adoption of the National Program for the Prevention of Juvenile Delinquency, the improvement of the legislative procedure for holding minors liable for administrative offenses and civil proceedings, as well as the standardization of football fan clubs' activities, were all recognized as the priority direction, due to the provisions of the European Convention on Violence and Misconduct by Spectators of 
Sports Events, in particular Football Matches $(1985)^{9}$, other international legal acts, as well as domestic law, taking into account the areas of legal regulation of preventive activities. Revival of youth leisure centers and the use of media opportunities are among the necessary measures of an organizational nature.

It is also necessary to distinguish a set of operative and preventive measures that should be aimed at identifying leaders and members of informal associations of football fans, ensuring public order during football matches and uninterrupted monitoring over the behavior of at-risk groups. Taking into account the international experience, it is necessary to delegate responsibilities for ensuring security in stadiums to specially trained teams of "spotters" from among law enforcement officers (with the simultaneous creation of intelligence bureaus - at the level of police departments and the National Football Information Point - at the state level).

The formation of the state principles of public order protection is a complex process aimed at updating and improving domestic legislation, and at adapting international experience in organizing the means, tools and methods of the National Police of Ukraine. The modern model of a democratic, social and legal state requires new conceptual approaches to solve the problems of implementing law enforcement function. Therefore, it is extremely important to generalize the experience of European Union countries in managing the activities of national police structures.

\section{CONCLUSION}

The priority task of the modern state is the formation of a healthy nation and the proper guaranteeing and regulation of various spheres of public life, which should contribute to improving the health and the physical and spiritual development of the population. Such areas as physical culture and sports are not the least important. Nowadays, certain socially dangerous phenomena have taken root in Ukraine in this area, in particular corruption, injuries, mortality, etc. Despite the large amount of information in the mass media and the Internet about socially dangerous manifestations that take place in the domestic physical culture and sports, there were no registered crimes in our country. The main reason for this is the existing imperfection of criminal and legal protection of this area in Ukraine, which is manifested in the lack of definition of crimes in the field of physical culture and sports and their classification.

9 European Convention on Spectators' Violence and Misconduct during Sports Events, in particular Football Matches dated from August 19, 1985. Verkhovna Rada of Ukraine. Available at: https://zakon.rada.gov.ua/laws/show/994_003. 
The crime prevention model cannot be designed if there are still obstacles or differences. Through the use of an integrated model, coordination can be maximized due to follow-up. The follow-up is a real action that is expected to give rise to the belief that the government is serious about making people live in prosperity and security. The purpose of designing an integrated model is that the designed model can increase knowledge to deal with the gaps, potentials and challenges faced, and it is predicted to be more dynamic. ${ }^{10}$

\section{REFERENCES}

A. O. Dzhuzha. Victimological Principles of Crime Prevention in UkRaine: Theory and Practice. National Academy of Internal Affairs. (2017).

A. V. Shesler. Group Crime: Criminological and CRiminal Aspects. Saratov State Law Academy. (2006).

Heny Batara Maya, Mohammad Kemal Dermawan \& Vinita Susanti. The Integrated Prevention Model for Marijuana Smuggling in Land Border Region of Indonesia-Papua Nugini (Case: Muara Tami District, Jayapura City, Papua Province. JuRnal CitA Hukum (INDONESIAN LAW JOURNAL) 3. 2020. Pg. 655-670. https://doi.org/10.15408/jch.v8i3.18421.

L. A. Rikina. International Cooperation of Ukraine in Combating Crime. SCIENTIFIC BULletin of DNIPROPETROVSK 4. 2004.

M. M. Rudyk. Prevention of Crimes Committed by Youth Football Groups in Ukraine. Kharkiv National University of Internal Affairs. (2016).

Rashin Ziya \& Ahmad Ahmadi. Criminological Study of Domestic Violence in Iran. JURNAL CITA HUKUM (INDONESIAN LAW JOURNAL) 3. 2020. Pg. 525-542. https://doi.org/10.15408/jch.v8i3. 18420

S. V. Alekseev. International Sports LaW. Yunita-Dana: Legislation and Law. (2008).

10 Heny Batara Maya, Mohammad Kemal Dermawan \& Vinita Susanti. The Integrated Prevention Model for Marijuana Smuggling in Land Border Region of Indonesia-Papua Nugini (Case: Muara Tami District, Jayapura City, Papua Province. JURNAL CITA HUKUM (INDONESIAN LAW JOURNAL) 3. 2020. Pg. 655-670. https://doi.org/10.15408/jch. v8i3.18421. 
14 Criminological principles of crime prevention in the field of physical culture and sports of Ukraine

V. V. Beletskiy. Violent Crime and Sports. Socio-legal Problems of Combating Violence: An InTERUNIVERsity Collection of SCIENTIFIC PAPERS. OYun. (1996).

Yu. M. Antonian. The Criminal Person and the Criminal's Personality. CriminologiCal PoInt of VIEW 3. 2008. 